\title{
Emigracja zarobkowa w kontekście zdrowia i choroby Nowy obszar teoretycznych i badawczych dociekań socjologii medycyny
}

\section{Wstęp}

W ostatnim czasie jednym z nowych obszarów eksploracji badawczej socjologów medycyny stała się emigracja zarobkowa. Intensyfikacja procesów migracyjnych związana z otwarciem rynków pracy tzw. „starej” UE dla Polski i innych krajów Europy Środkowo-Wschodniej, podejmowanie nowych strategii migracyjnych, w tym migracji wahadłowej, migracji cyrkulacyjnej, powodują pojawienie się nowych problemów natury polityczno-ekonomicznej, ale także natury zdrowotnej. Już nestorka polskiej socjologii medycyny, Magdalena Sokołowska, zwracała uwage, iż migracje $\mathrm{z}$ jednego kraju do drugiego moga być czynnikiem wpływającym na wzrost występowania chorób somatycznych (Sokołowska 1986: 53). W artykule podejmę próbę analizy psychospołecznych uwarunkowań zdrowia emigrantów i stanu zdrowia, posługując się zgromadzonym materiałem badawczym, na który składaja się wywiady jakościowe z emigrantami i ich rodzinami. Drugim celem artykułu będzie próba odpowiedzi na pytanie o możliwość konstrukcji modelu analizy zdrowia emigrantów.

\section{Zdrowie i choroba - podstawowe kategorie analizy socjologii medycyny ${ }^{1}$}

Zanim przejdę do sedna interesujacego mnie tematu zdrowia emigrantów, podejmę próbę osadzenia go w szerszych ramach teoretyczno-badawczych socjologii medycyny oraz dokonam przeglądu i wyboru definicji pojęć, którymi będę się posługiwać w dalszych analizach.

\footnotetext{
${ }^{1}$ Warto odnotować fakt, że wielu socjologów zajmujących się problemami z zakresu socjologii medycyny woli posługiwać się inną nazwą subdyscypliny, pisząc o socjologii choroby, zdrowia i medycyny, ponieważ ich zdaniem nazwa ta jest bardziej adekwatna dla rzeczywistego zakresu zainteresowań badawczych socjologów medycyny, którzy analizują społeczny, kulturowy i behawioralny kontekst zdrowia i choroby człowieka (zob.: Piątkowski 2010: 27; Latoszek 1998: 351).
} 
Autorka jednego z podręczników poświęconych zagadnieniom socjologii medycyny, Sarah Nettelton, definiuje tę subdyscyplinę jako obejmująca „wszystkie aspekty współczesnego życia człowieka społecznego, które wpływają na zdrowie w ciagu całego cyklu życia" (Nettelton 2006: 1).

W ramach współczesnej socjologii medycyny wyodrębnia się trzy główne podejścia:

1. Podejście makrostrukturalne - w jego ramach analizuje się m.in. wpływ wskaźników położenia społecznego, płci i stresu w dystrybucji zdrowia i chorób w społeczeństwie, a więc bada się nierówności zdrowotne. W badaniach tych przyjmuje się, iż czynniki socjokulturowe odgrywają kluczową rolę w determinowaniu stanu zdrowia jednostek i społeczeństwa.

2. Podejście mikrostrukturalne - $\mathrm{w}$ tym podejściu przedmiotem analiz socjologicznych sa m.in. sposoby doświadczania choroby, interakcje między pacjentami a personelem medycznym.

3. Podejście mikro-makro - stosuje się je w badaniu interakcji pacjent-lekarz z uwzględnieniem szerszego kontekstu instytucjonalnego, politycznego lub ekonomicznego (Skrzypek, Popielski, Albińska 2010: 30-31).

Badania zdrowia emigrantów wpisuja się w dużej mierze w podejście makrostrukturalne. Ryzyko zdrowotne w odniesieniu do emigracji zarobkowych można postrzegać jako rezultat globalnego podziału pracy wynikającego z nierówności społecznych i powodującego pogłębianie się tych nierówności, co znajduje swoje odbicie także w występowaniu nierówności zdrowotnych. W tym ujęciu emigracja zarobkowa jawi się jako jeszcze jedna płaszczyzna przejawiania się nierówności zdrowotnych, a także czynnik powodujący i/lub pogłębiający owe nierówności.

Kluczowymi pojęciami dla analiz skoncentrowanych na uwarunkowaniach zdrowia emigrantów i na samym zdrowiu emigrantów są pojęcia zdrowia i choroby, a także pojęcia ryzyka zdrowotnego, stylu życia, jakości życia oraz nierówności zdrowotnych.

W socjomedycznych ujęciach kategoria zdrowia jest definiowana bardzo szeroko jako pojęcie przeciwne chorobie albo jako stan pozytywny. W aspekcie pozytywnym zwraca się uwage na zapas zdrowia, potencjał zdrowia, jakim człowiek dysponuje i który decyduje o jakości jego życia. Zdrowie jest zatem postrzegane jako zbiór możliwości, który daje jednostce swobode wyboru i wolność robienia tego, co chce (Piątkowski 2002b: 31). Najczęściej przywoływana przez socjologów medycyny jest definicja zdrowia Światowej Organizacji Zdrowia z 1948 r., w której czytamy, iż zdrowie to nie tylko brak choroby, ale także stan pełnego dobrostanu fizycznego, psychicznego i społecznego (Uramowska-Żyto 2009: 66-67). 
Brak zdrowia można rozumieć na trzy sposoby:

1. Jako chorobe $\mathrm{w}$ sensie biologicznym, czyli patologiczna zmianę organizmu, która może określić kompetentny lekarz (disease).

2. Jako chorobę $\mathrm{w}$ sensie samopoczucia danego człowieka, a więc chodzi tu o subiektywnie odczuwany stan, poczucie dyskomfortu (illness).

3. Jako chorobe w sensie socjologicznym, a zatem stanu odbieranego przez innych bez względu na to, czy choroba występuje w sensie biologicznym lub psychologicznym czy nie (sickness) (Uramowska-Żyto 2009: 67).

Badajac psychospołeczne uwarunkowania chorób, trzeba każdorazowo określać, w jakim znaczeniu używa się tego pojęcia. W badaniach socjologicznych częściej mówi się o chorobie w sensie odczuwania subiektywnego stanu lub stanu odbieranego przez otoczenie jako chorobowy. Badając częstotliwość występowania określonych chorób i próbując określić ich psychospołeczne podłoże, socjologowie często sięgają także do statystyk medycznych i epidemiologicznych, i wówczas mowa jest o chorobie w sensie biologicznym.

W licznych publikacjach z zakresu socjologii medycyny podkreśla się, iż choroba nie jest wyłącznie efektem zadziałania czynników szkodliwych dla zdrowia. Jej wystapienie jest także pochodna indywidualnej odporności jednostki na działanie tych czynników, pewnych cech osobowości ułatwiających lub utrudniających człowiekowi radzenie sobie z problemami życiowymi, jak również dostępu i umiejętności korzystania z zasobów pomocy i wsparcia oferowanych przez najbliższe otoczenie (Firkowska-Mankiewicz 2009: 51-52).

Szacuje się, iż styl życia i środowisko mają decydujacy wpływ na zdrowie jednostki i społeczeństwa. Mówi się nawet, iż styl życia w ok. 70\% wpływa na zdrowie jednostki (Waszkiewicz 2002: 98). W niniejszym opracowaniu będe się posługiwać definicja stylu życia zaproponowana przez Andrzeja Sicińskiego, który pod pojęciem stylu życia rozumie: „zakres i formy codziennych zachowań jednostek i grup, specyficzne dla ich usytuowania społecznego, tzn. manifestujące położenie społeczne oraz postrzegane jako charakterystyczne dla tego położenia, a dzięki temu umożliwiajace szeroko rozumiana społeczna lokalizacje innych ludzi” (Siciński 1976: 15). Definicja ta kładzie nacisk na społeczne usytuowani, jako determinantę kształtowania określonego stylu życia, a z drugiej strony jako płaszczyzne przejawiania się wybranego stylu życia. Z kategoria styl życia współgra pojęcie jakości życia, które może być definiowane i badane z użyciem wskaźników obiektywnych lub subiektywnych. Do wskaźników obiektywnych zaliczamy poziom materialny, zabezpieczenie finansowe, warunki życia i mieszkania, warunki leczenia, 
bezpieczeństwo ekologiczne, relacje społeczne, system wsparcia społecznego, aktywność społeczną, rozwój osobisty (edukacja, praca, uczestnictwo w kulturze) czy też rekreację i wypoczynek. Z kolei subiektywny pomiar jakości życia kładzie nacisk na poziom stanu zaspokojenia potrzeb, takich jak potrzeba bezpieczeństwa i poczucia wewnętrznego spokoju, realizacji życiowych celów oraz aspiracji, stopnia samoakceptacji, dobrostanu psychicznego, akceptacji społecznej czy uznania społecznego (Trzebiatowski 2011: 28). Jakość życia jest w wyraźny sposób skorelowana ze stylem życia, a ten ze wspomnianym już społecznym usytuowaniem i doświadczanym w związku z niskim usytuowaniem stanem deprywacji zaspokojenia określonego rodzaju potrzeb, m.in. potrzeb związanych ze zdrowiem i dbałością o nie.

Nierówności zdrowotne wyrastają z nierówności społecznych i sa przez nie determinowane. Nierówność społeczna występuje, kiedy jednostka lub grupa z racji swej pozycji społecznej korzysta w większym stopniu niż inne z dóbr będących przedmiotem aspiracji ogółu. Uprzywilejowane - lub nie - umiejscowienie w strukturze społecznej wpływa nie tylko na szanse życiowe jednostki, lecz także determinuje styl życia, który przekłada się na zapadalność ludzi na określone choroby, długość ich życia oraz na sposób postrzegania choroby i reakcję na nią. $\mathrm{W}$ badaniach nierówności zdrowotnych stosuje się takie zmienne, jak: wiek, płeć, stan cywilny, wykształcenie czy dochód (Synowiec-Piłat 2002: 89-90).

W'́ród czynników pośredniczących między niskim statusem socjoekonomicznym a wyższymi wskaźnikami zachorowalności na choroby przewlekłe i wyższymi wskaźnikami śmiertelności wymienia się: industrializację i urbanizację, mobilność geograficzną i zawodowa, trudne warunki pracy lub brak pracy, rozpad więzi rodzinnych, trudności w realizacji ról społecznych (Firkowska-Mankiewicz 2009: 49).

Powyższe zjawiska wiąża się w sposób bezpośredni lub pośredni z emigracją zarobkowa. Emigracja zarobkowa jest przecież rodzajem mobilności geograficznej. Emigranci bardzo często sa zmuszeni do ciężkiej pracy w trudnych i bardzo trudnych warunkach. Ponadto rozłaka z rodzina grozi rozpadem więzi, a pełnione dotychczas role społeczne wymagaja redefinicji lub częściowego zawieszenia (rola rodzica, współmałżonka). Jeśli dodamy do tego potwierdzony licznymi badaniami fakt, iż znaczna część poakcesyjnej fali emigracji zarobkowej to emigracje „przeżycia” a nie emigracje "sukcesu” (Markowski 2008: 41), to wówczas otrzymamy niezbyt optymistyczny obraz sytuacji typowego polskiego emigranta, który w efekcie działania czynników obiektywnych (warunki pracy i mieszkania, sytuacja oddalenia) i czynników subiektywnych (jednostkowa odporność fizyczna i psychiczna) jest przypuszczalnie kilkakrotnie 
bardziej narażony na zachorowanie na choroby cywilizacyjne i innego typu uszczerbki na zdrowiu. Pytanie, czy poziom tego zagrożenia da się w sposób dokładny zmierzyć.

Na koniec warto podkreślić, iż badając społeczne podłoże mogace mieć związek z zachorowalnością na określone choroby psychiczne lub somatyczne, stosuje się różne podejścia. Jednym z nich jest podejście funkcjonalne, traktujące chorobę jako zagrożenie dla właściwego pełnienia ról społecznych, a tym samym integralności systemu społecznego. W ramach konkurencyjnego, bliższego autorce artykułu, podejścia interakcjonistycznego badacze skupiaja się na analizie zdroworozsądkowej wiedzy, życia codziennego oraz przemian zachodzacych w subiektywnej i obiektywnej rzeczywistości w zakresie spraw związanych ze zdrowiem (Uramowska-Żyto 2009: 70-75).

Podsumowujacc - badając zdrowie emigrantów i stopień ich narażenia na różne formy ryzyka zdrowotnego, stosuje podejście mikro-makro, gdyż:

1) z jednej strony interesuja mnie zewnętrzne uwarunkowania emigracji - globalny podział pracy, nierówności społeczne i związane z nimi nierówności zdrowotne, stopień narażenia na czynniki ryzyka zdrowotnego, w tym realizowany styl życia;

2) z drugiej strony koncentruję się na zdrowiu emigrantów jako stanie doświadczanym subiektywnie, czyli badam poczucie bycia chorym lub zdrowym, umiejscawianie choroby i stosunek do niej $\mathrm{w}$ indywidualnej biografii emigranta, poczucie indywidualnej odpowiedzialności za swój stan zdrowia i poczucie sprawstwa w odniesieniu do zdrowia i choroby.

\section{Chorujący emigrant w świetle dotychczasowych badań}

Dopiero od kilku lat dostrzegane jest wysokie ryzyko utraty zdrowia w związku z emigracją, które wzrasta wraz z nasileniem się procesów migracji zarobkowej (Kawczyńska-Butrym 2009:193). W ramach polskiej socjologii medycyny badanie zdrowia emigrantów i czynników mogacych mieć na nie wpływ nie jest często podejmowanym tematem. Analizujacc literature przedmiotu, odnalazłam jedynie dwie prace podejmujące ten temat, do których będę się tu odnosić. Zdecydowanie częściej problematyka ta jest obecna wśród badaczy z krajów Europy Zachodniej i Stanów Zjednoczonych, a więc obszarów będących w skali globalnej najpopularniejszymi kierunkami docelowymi emigrantów.

Pierwszy wniosek, jaki się nasuwa, to stwierdzenie, że zdrowie emigrantów jest częściej analizowane z perspektywy kraju przyjmującego 
niż kraju wysyłającego. Z pewnością jakiś związek z popularnością tematu zdrowia emigrantów w krajach emigracji netto ma konieczność dopasowania polityki migracyjnej i polityki zdrowotnej do problemów generowanych przez duże grupy migrantów zarobkowych czy uchodźców politycznych. Wynika to z tego, iż chorujący emigranci obciążaja system opieki zdrowotnej i społecznej kraju przyjmującego. Tymczasem warto zauważyć, iż wobec powszechności wahadłowej strategii emigrowania problemy zdrowotne powodowane $\mathrm{w}$ bezpośredni lub pośredni sposób przez emigrację zarobkową moga stać się wyzwaniem także dla kraju wysyłajaccego, ponieważ emigrant może szukać pomocy medycznej także tu. Ponadto, problemy zdrowotne dotykają również reemigrantów, a niektóre z nich mogą się ujawnić po pewnym czasie, kiedy to emigracja staje sie oddalonym w czasie epizodem w jednostkowej biografii. W ekstremalnych sytuacjach emigranci sa zmuszeni do powrotu do domu w związku ze złym stanem swojego zdrowia spowodowanym wystąpieniem przewlekłej choroby, stając się poważnym obciążeniem dla instytucji medycznych i zajmujacych się pomoca socjalną (Davies, Borland, Blake, West 2011: 1-5).

$\mathrm{Z}$ tych przyczyn poświęcenie uwagi badaniu emigracji jako kontekstu dla pojawienia się i działania czynników ryzyka zdrowotnego staje się koniecznością i wstępem do podjęcia praktycznych działań w ramach polskiego systemu zdrowotnego, nakierowanych na rozwiazanie problemów i analizę potrzeb tej specyficznej grupy pacjentów.

W badaniach nad zdrowiem emigrantów można przyjąć dwa podejścia:

1. Skoncentrować się na analizie przypadłości zdrowotnych dotykających osoby emigrujące i porównywać częstotliwość ich występowania w grupie emigrantów i w grupie kontrolnej.

2. Badać czynniki, które moga mieć prawdopodobny negatywny wpływ na zdrowie emigrantów.

Można też oba te podejścia stosować łącznie w różnych proporcjach.

W badaniach poświęconych zdrowiu emigrantów można potraktować emigrację albo jako bezpośredni czynnik powodujacy częstotliwość występowania określonych chorób (np. stanów depresyjnych, lękowych), albo jako czynnik pośredni wpływający na stan zdrowia emigrantów poprzez generowanie określonego typu ryzyk zdrowotnych, które moga powodować wystapienie pewnych, specyficznych dla sytuacji emigracji, chorób bądź zwiększać częstotliwość zachorowania emigrantów na tzw. choroby cywilizacyjne. W moim przekonaniu właściwsze jest to drugie podejście. Powołuje się tu na pogląd Anny Firkowskiej-Mankiewicz, która uważa, iż związki między czynnikami społeczno-kulturowymi a zdrowiem stanowią „sieć wzajemnie się warunkujacych zależności pośrednich”, 
niespecyficzny, skomplikowany, wielowymiarowy, zmieniajacy się dynamicznie układ (Firkowska-Mankiewicz 2009: 58).

Analizujac emigracje zarobkowe pod katem generowanych przez nie ryzyk zdrowotnych, będe posługiwać się klasyfikacja psychologicznych i zdrowotnych ryzyk migracji stworzona przez B. Wasilewskiego i M. Kosewskiego, którzy wyróżnili następujące kategorie wspominanych ryzyk:

1. Bezpośrednie: a) trauma wyjazdu, b) reakcje emocjonalne związane z nowym środowiskiem.

2. Krótkoterminowe: a) zaniechania i zagrożenia zdrowotne, b) reakcje psychosomatyczne.

3. Długoterminowe: a) niekorzystne następstwa rodzinne, b) przewlekłe problemy psychiczne, c) zaburzenia tożsamości (Wasilewski, Kosewski 2006).

Do tej listy można dodać również inne czynniki, m.in. szok kulturowy i procesy akulturacji, które też mogą stwarzać podatny grunt dla rozwoju różnego typu ryzyk zdrowotnych.

Ponadto czynniki te można podzielić, biorąc pod uwage stopień kontroli emigranta nad znalezieniem się pod wpływem ich działania.

Z tabeli 1 wynika, iż na występowanie większej liczby czynników ryzyka zdrowotnego emigrant ma pewien wpływ. Jednym z takich czynników jest funkcjonowanie emigranta w dotychczasowych układach społecznych, głównie w rodzinie w sytuacji czasowego oddalenia. Ten czynnik omówię tu szerzej. Z uwagi na ograniczone ramy artykułu, nie sposób dokonać pełnego opisu pozostałych czynników, a po drugie, zdrowie i rodzina sa jednymi z najważniejszych wartości uznawanych przez społeczeństwa niezależnie od kultury czy szerokości geograficznej. Obie mają bardzo ważne znaczenie w przebiegu ludzkiego życia, przenikaja się wzajemnie i oddziałują na siebie. To ich wzajemne sprzężenie można zwłaszcza dostrzec $\mathrm{w}$ tych sytuacjach, kiedy następuje całkowita lub częściowa utrata jednej z nich, np. zdrowia (w efekcie choroby czy pojawienia się niepełnosprawności) lub rodziny (w efekcie osłabienia więzi, dysfunkcjonalności czy rozpadu) (Kawczyńska-Butrym 2009: 194).

Jak pisze L. Nowakowska, powołując się na wyniki raportu International Migration and Health z 2005 r., proces migracji stwarza określone zagrożenia dla zdrowia psychicznego i ogólnego samopoczucia osób migrujacych także m.in. poprzez zagrożenie ryzykiem rozpadu więzi rodzinnych. Wskaźnik rozwodu wśród migrantów jest statystycznie wyższy w porównaniu z ogólna populacją kraju przyjmujacego. Stwierdzono także większy negatywny wpływ rozwodu migrantów na ich dzieci niż w przypadku nieemigrantów (Carballo, Mboup 2005 za Nowakowska 2010: 289). Z licznych badań na temat zróżnicowań i nierówności społecznych w kontekście zdrowia wiadomo, że osoby rozwiedzione 
sa bardziej narażone na zapadnięcie na przewlekłe choroby czy ryzyko wczesnej śmierci niż osoby pozostające w związkach. Dzieje się tak, ponieważ pozostawanie w związu zapobiega izolacji społecznej. Rodzina jest także niezastapionym źródłem emocjonalnego wsparcia, a także sprzyja prowadzeniu prozdrowotnego stylu życia (Synowiec-Piłat 2002: 91-92; Firkowska-Mankiewicz 2009: 54).

Tabela 1. Ryzyko zdrowotne w kontekście emigracji - czynniki

\begin{tabular}{|c|c|}
\hline $\begin{array}{l}\text { Czynniki wynikajace z działań } \\
\text { i doświadczeń jednostkowych }\end{array}$ & $\begin{array}{c}\text { Czynniki wynikajace z ogólnej } \\
\text { sytuacji emigracji }\end{array}$ \\
\hline $\begin{array}{l}\text { - Złe warunki mieszkaniowe i sanitarno- } \\
\text {-epidemiologiczne } \\
\text { - Podejmowanie pracy wyczerpującej fizycznie } \\
\text { i/lub psychicznie, tzw. pracy „3d” - dull, } \\
\text { dirty and dangerous } \\
\text { - Brak (nielegalna praca oznacza brak } \\
\text { ubezpieczenia zdrowotnego) lub } \\
\text { niedostateczna opieka zdrowotna, także } \\
\text { w odniesieniu do zdrowia psychicznego } \\
\text { - Ograniczone relacje społeczne w nowym } \\
\text { środowisku z emigrantami i autochtonami } \\
\text { (nieznajomość języka, nieznajomość kodów } \\
\text { kulturowych, zasad komunikacji, niechęć } \\
\text { do integrowania się, brak umiejętności } \\
\text { funkcjonowania w środowisku } \\
\text { wielokulturowym) } \\
\text { - Złe odżywianie się spowodowane } \\
\text { koniecznościa oszczędzania } \\
\text { - Brak odpoczynku, niedobory snu } \\
\text { spowodowane podejmowaniem kilku zajęć } \\
\text { jednocześnie } \\
\text { - Zaburzenia funkcjonowania } \\
\text { w dotychczasowych układach społecznych, } \\
\text { np. zaburzenia relacji w rodzinie } \\
\text { - Presja na osiagnięcie sukcesu } \\
\text { - Stres } \\
\text { - Poczucie wykorzenienia } \\
\text { - Osamotnienie } \\
\text { - Obwinianie się o niepowodzenia } \\
\text { - Przejawy anomii społecznej skutkujące } \\
\text { zwiększona liczba samobójstw }\end{array}$ & $\begin{array}{l}\text { - Trauma zmiany społecznej } \\
\text { i konieczność przystosowania się do } \\
\text { nowych społeczno-ekonomicznych } \\
\text { warunków } \\
\text { - Marginalizacja społeczna, także } \\
\text { marginalizacja ekologiczna } \\
\text { (zamieszkiwanie miejsc o większej } \\
\text { skali przestępczości i występowania } \\
\text { innych form patologii) } \\
\text { - Szok kulturowy } \\
\text { - Dostęp do służb społecznych } \\
\text { i medycznych (np. w zakresie } \\
\text { transkulturowych zasobów } \\
\text { indywidualnych osoby migrującej } \\
\text { oraz rodzaju posiadanego statusu } \\
\text { - przebywanie legalne lub nielegalne) } \\
\text { - Polityka migracyjna danego kraju } \\
\text { - im bardziej restrykcyjna jest to } \\
\text { polityka, tym bardziej zdrowie } \\
\text { emigrantów jest zagrożone }\end{array}$ \\
\hline
\end{tabular}

Źródło: opracowanie własne.

Kolejny wniosek z raportu jest taki, iż obserwuje się wśród emigrantów zjawisko idealizowania własnej rodziny, co przejawia się izolowaniem 
oraz dystansem wobec nowego otoczenia społecznego, a to przekłada się na nieumiejętność budowania nowej sieci wsparcia społecznego niezbędnej do zachowania równowagi psychospołecznej (Carballo, Mboup 2005 za Nowakowska 2010: 289). Jest to widoczne zwłaszcza w odniesieniu do emigrantów wahadłowych, których strategia emigracji nie pozwala na zakorzenienie się w nowym miejscu i stanie się członkiem jakieś społeczności w kraju emigracji, która nie byłaby społecznością emigrantów z kraju lub regionu pochodzenia.

Osoby, które posiadają co najmniej jednego członka rodziny w kraju przyjmujacym, cechowały się lepszym zdrowiem psychicznym niż migranci, którzy nie posiadaja tego rodzaju wsparcia. Wśród migrantów stwierdza się częstsze występowanie schizofrenii, uzależnień od alkoholu i narkotyków oraz wyższy wskaźnik depresji i samobójstw. Poziom ryzyka wystąienia tych problemów jest uzależniony od kilku czynników, m.in. od przyczyny migracji, statusu emigranta w kraju przyjmującym czy „podobieństwa kulturowego” kraju przyjmującego (Carballo, Mboup 2005 za Nowakowska 2010: 291; Leao, Sundquist, Johansson, Sundquist 2009: 93).

W związku z doświadczaniem ogromnego stresu w sytuacji emigracji może być ona traktowana także jako czynnik wystąpienia ryzyka chorób somatycznych zarówno wśród emigrantów, jak i nieemigrujacych członków ich rodzin. Jak wiadomo, wiele chorób somatycznych może mieć psychospołeczne podłoże. Wśród emigrantów z różnych krajów obserwuje się wzrost zachorowalności na wrzody żołądka, chroniczne bóle głowy, choroby układu krążenia, cukrzyce.. Innym powodem częstszej zachorowalności emigrantów na te choroby jest antyzdrowotny styl życia. Warto też odnotować, iż w związku z podejmowaniem przez osoby emigrujące (głównie mężczyzn) zajęć niebezpiecznych i prac wykonywanych z trudnych warunkach wzrasta też wśród nich ryzyko wystapienia chorób zawodowych, wypadków czy urazów (Nowakowska 2010: 293).

Skupienie się na zdrowiu emigrantów i reemigrantów również z perspektywy kraju wysyłającego jest konieczne z uwagi na to, iż często emigranci w obszarze zdrowia przyjmuja strategie pracy „tam” i leczenia się „tu”. Ponadto, zdrowotne skutki emigracji mogą dotknąć członków ich rodzin przebywajacych w kraju. Dlatego też socjomedyczne badania zdrowia emigrantów powinny się skupiać nie tylko na emigrancie, ale także na jego rodzinie, będacej punktem odniesienia emigranta i adresatem jego różnorakich działań. 


\section{Zdrowie emigrantów - możliwości wnioskowania w oparciu o dane jakościowe}

Obecną falę emigracji cechuje duża liczebność i duża dynamika, która nie pozwala na jednoznaczne stwierdzenie, ile dokładnie osób opuściło kraj, by pracować i żyć za granicą. Z badań CBOS z 2008 r. wynika, że w ciagu dziesięciu lat co jedenasty Polak pracował za granica. Tego typu doświadczenia dwukrotnie częściej mają mężczyźni niż kobiety. Szczególnie licznie wyjechały osoby z grupy wiekowej 25-34 lata (Praca Polaków za granica... 2008)2 ${ }^{2}$.

Cechą współczesnych emigracji zarobkowych jest transnacjonalizm, będący procesem tworzenia i podtrzymywania przez migrantów różnego rodzaju relacji łączących społeczeństwo pochodzenia i społeczeństwo osiedlenia. Transnarodowa perspektywa dotyczy nie tylko tych, którzy wyjechali, lecz także tych, którzy pozostali na miejscu i dzięki swoim bliskim maja transnarodowe powiązania (Trabka 2009: 74-75). Funkcjonowanie w transnacjonalnych warunkach jest pochodna wahadłowej strategii emigrowania. Emigrację wahadłową charakteryzuja następujace cechy:

- jest to emigracja krótkotrwała - jednorazowy pobyt emigranta waha się od kilku tygodni do kilku miesięcy;

- w tym typie emigracji dominuja motywy zarobkowe;

- jest to emigracja nieregularna - okresy pobytu na emigracji i w kraju macierzystym są zmienne. Obserwuje się, iż w miarę wydłużania się czasu trwania emigracji zmniejsza się częstotliwość i długość okresu, na który emigrant wraca do kraju pochodzenia (Niedźwiecki 2010: 21, 25, 41; Grabowska-Lusińska, Okólski 2009: 42).

Badania jakościowe wśród emigrantów wahadłowych prowadzę od 2010 r. Do tego momentu udało mi się zebrać dane od następujacych grup emigrantów wybieranych metoda „kuli śniegowej”:

- lato 2010 r. - wywiady z rodzicami emigrujacymi i ich partnerami (44 wywiady);

- lato 2011 r. - wywiady z emigrantami singlami (24 wywiady);

- lato 2012 r. - wywiady z: rodzicami emigrujaccymi i ich partnerami (15 wywiadów); rodzicami bez doświadczeń emigracyjnych (16 wywiadów); emigrantami-singlami (16 wywiadów).

\footnotetext{
${ }^{2}$ Badanie przeprowadzono w dniach 7-8 października 2008 r. na liczącej 1107 osób reprezentatywnej próbie losowej dorosłych mieszkańców Polski (Praca Polaków za granica... 2008).
} 
Do tej pory cała próba badawcza liczy 115 osób. Z uwagi na brak możliwości przedstawienia pełnych porównawczych wyników badań ze wszystkich grup badanych skoncentruję się na analizie wywiadów rodziców emigrujących i partnerów, przeprowadzonych latem 2012 r. Wybrałam do analizy tę grupę badanych, ponieważ w związku z ewolucja dyspozycji do wywiadu i koncepcji badania w miare pojawiania się nowych danych w przypadku wywiadów z ostatniej tury pojawiło się najwięcej pytań odnoszących się do czynników ryzyka zdrowotnego $\mathrm{w}$ odniesieniu do emigranta $\mathrm{i}$ jego rodziny.

Ryzyko zdrowotne wśród emigrantów szacowałam na podstawie odpowiedzi badanych na pytania o:

1. Rytm dnia badanego (chodziło o zidentyfikowanie potencjalnych czynników ryzyka zdrowotnego, takich jak nieregularność posiłków, zbyt mały czas poświęcony na wypoczynek i sen, intensywność pracy w ciągu dnia, sposoby relaksowania się itd.).

2. Korzystanie z pomocy służby zdrowia na emigracji (jak długo, w jakim celu, jakiego rodzaju była to pomoc).

3. Ocenę, czy praca przez nich wykonywana ma lub może mieć negatywny wpływ na ich zdrowie fizyczne lub psychiczne.

Reasumujac, do analizy zdrowia emigrantów wykorzystałam dwa wskaźniki obiektywne - opis rytmu dnia codziennego, korzystanie z pomocy służby zdrowia, oraz jeden wskaźnik subiektywny - samoocene emigranta dotycząca potencjalnej szkodliwości pracy dla jego zdrowia. Interesował mnie także wpływ migracyjnego kapitału społecznego na większą lub mniejsza podatność na różne formy ryzyka zdrowotnego, ale jego analiza zostanie tu pominięta.

Charakterystyka tej grupy badanych przedstawia się następująco:

- wśród rodziców emigrujących dominowali mężczyźni;

- w większości emigrowały osoby młode z dwóch grup wiekowych 20-30 lat i 31-40 lat;

- emigranci mieli w przeważającej mierze wykształcenie średnie ogólne, średnie techniczne lub wykształcenie wyższe, ich partnerzy - podobnie;

- emigrowali głównie do Wielkiej Brytanii, Irlandii, Holandii, Szwecji, Niemiec i Francji;

- najczęściej spotykanym w tej grupie modelem rodziny była rodzina $2+1$ lub $2+2$;

- najmłodsze dziecko miało 3 miesiace w czasie emigracji rodzica, najstarsze - 22 lata. 


\section{Rytm dnia rodzica emigrującego}

Rytm dnia badanych wyznaczała praca. Często była to praca wielogodzinna, nierzadko od rana do wieczora. Niekiedy badani pracowali na dwa etaty, by maksymalnie wykorzystać czas emigracji i zebrać potrzebny kapitał finansowy. Życie na emigracji to życie praca i dla pracy. Respondenci nastawiaja się na kilkumiesięczne okresy intensywnej pracy i kilkutygodniowe okresy rekonwalescencji w domu. W ciagu tych kilku miesięcy uczą się żyć z obciążeniami w postaci braku snu, nieregularnych posiłków i niezbyt dobrych warunków mieszkaniowych. W przypadku większości badanych wyjazdy miały być jednorazowe, ale $\mathrm{z}$ reguły po pierwszym wyjeździe następowały kolejne i pojawiło się przyzwyczajenie do takiego schematu życia. Oto przykładowe wypowiedzi badanych:

Teraz dość tak, dość regularnie od godziny wpót do siódmej do siedemnastej, a przez te dziewięć lat $w$ tej Life firmie to różnie byto, to byto tak, że od siódmej do jedenastej $w$ nocy, do wpót do dwunastej, do dziewiatej, do ósmej (RE24m: 110-113) ${ }^{3}$.

No $z$ ludźmi $z$ pracy to $w$ soboty chodziliśmy sobie zawsze na piwko do pobliskiego baru, ale tak to gtównie rozmawiatem tam z kierowcami, których znałem już $z$ Polski, $i$ też jakoś $w$ weekendy spędzaliśmy czas razem, czasem wyjście na ryby, jakaś wycieczka, czy też wyjście na piwo wieczorem (RE25m: 156-159).

Po pracy następuje krótki okres odpoczynku, podczas którego badani zwykle przebywają w gronie innych emigrantów i oddaja się prostym rozrywkom (telewizja, wizyta $\mathrm{w}$ pubie) lub dzwonią do rodzin. Telefon do domu też często ma miejsce o jednej i tej samej porze, co wprowadza pewna harmonię i poczucie kontroli nad sytuacją. Czas wytężonej pracy na emigracji pozwala przetrwać podzielane przez wielu emigrantów przekonanie, że to tylko na chwilę i że praca na emigracji to taka przymusowa przerwa w normalnym życiu. Ogółem emigranci nie mieli zbyt wielu okazji do „rozładowania” negatywnych emocji związanych

\footnotetext{
${ }^{3}$ Wyjaśnienia odnośnie do symboli, którymi zostały oznaczone wywiady. Wywiady z rodzicami stacjonarnymi zostały oznaczone symbolem RS, numerem porządkowym oraz literka „m” (mężczyzna) i „k” (kobieta), a wywiady z rodzicami emigrującymi - symbolem RE, jak również numerem porządkowym (w przypadku par małżeńskich te numery były analogiczne) i literka „m” lub „k”, a więc np. symbol RE17m - oznacza mężczyznę-emigranta.
} 
z napięciami w pracy czy problemami rodzinnymi. To „rozładowywanie” następowało przeważnie w okresie bytności w domu i wiązało się z przesadnie nerwowymi reakcjami na wydarzenia mające wówczas miejsce.

\section{Korzystanie z pomocy służby zdrowia na emigracji}

Każdemu z badanych zdarzyło się przynajmniej raz skorzystać z pomocy służby zdrowia lub znaja kogoś, kto korzystał lub komu pomogli podczas wizyty w szpitalu. Przeważa zdziwienie inna „filozofia leczenia" - nastawieniem na natychmiastowa pomoc choremu i zapewnienie mu wszelkich niezbędnych środków, np. darmowych leków.

No przy pomocy męża kuzynki musiałem skorzystać wtedy ten jeden raz, to jak mi wywalita ta rwa kulszowa, to się nie dało wytrzymać po prostu, nie dato sie wytrzymać, przeciażytem kregostup i tam miatem ucisk na dysku, no i tak mnie złapato, że nie mogtem $z$ tego wyjść. [...] No catkiem inna, ja bytem zszokowany, jak tam jest, jak pojechaliśmy na przychodnie, no to powiem Ci, że, wiesz, ani kolejki, ani dzień dobry, tylko tam po szwedzku oczywiście, to bytem zszokowany (RE26m: 147-50; 154-56).

Najczęściej jednak badani korzystali z pomocy służby zdrowia $\mathrm{w}$ kraju emigracji w sytuacji wypadku lub nagłego pogorszenia się stanu zdrowia - rwa kulszowa, ból zęba itd. Zazwyczaj wówczas opisywana przez badanych sytuacja była nieumiejętność odnalezienia się w sytuacji wymagającej interwencji lekarskiej w związku z trudnościami językowymi i często występującym strachem, że trzeba jednak będzie za tak dobra opiekę zapłacić. Inne dolegliwości, niewymagające nagłej pomocy medycznej badani leczyli podczas okresów pobytu w domu. Wiązało się z tym też przekonanie, że pracodawcy za granica jeszcze mniej chętnie niż w kraju zatrudniają osoby biorace nawet krótkie urlopy zdrowotne.

\section{Ocena warunków pracy}

Badanych przeze mnie respondentów dotknęło w większości zjawisko „marnotrawstwa mózgów” (brain waste), czyli podejmowanie pracy poniżej kwalifikacji (Trabka 2009: 78). Zwykle praca miała miejsce w trudnych warunkach, była bardzo ciężka. Ponieważ były to proste prace fizyczne, to nie skutkowały one bezpośrednio problemami natury psychicznej. Jednakże jednostajność zajęcia powodowała znużenie 
i poczucie „stania w miejscu”, braku możliwości rozwoju zawodowego. Badani zwykle starali się swoją sytuację racjonalizować poprzez przekonywanie siebie, że to nie na stałe i że nagrodą za trudy sa zarobione pieniądze, za które w kraju będzie można „pożyć”.

Praca nielekka, nieprzyjemna, ciężka, brudna, no i co, ale pieniadze wynagradzaja (RE26k).

Trudne, bo $w$ sumie oni byli w porzadku i tak dalej, no, ale mieszkaliśmy $w$ takim, barakowóz czy coś takiego, tylko, że tam w tym baraku warunki socjalne byty super no, ale wiadomo, nie jest to $w$ domu tylko $w$ barakowozie nie, ale byt prysznic, byt kibel, byto wszystko, nikt sie nas nie czepiat. Tylko ciężka praca byta, tam byta od 7 do 18 [...] Tam $w$ tych Niemczech schudtem $20 \mathrm{~kg}$ (RE31m:127-32).

Emigracja partnera jest też obciążeniem dla pozostającej w kraju „drugiej połowy”, o czym świadczą przytoczone poniżej odpowiedzi.

Znaczy ja czasem panikuje $i$ czasem jest tak, że ja mówię, że ja tego nie przeskocze wszystkiego, ja nie dam rady wszystkiego załatwić, ale człowiek jakoś tak sam sobie chyba, nie wiem jak to powiedzieć, sam sobie utrudnia $\dot{z} y c i e$, bo marudzi, sobie wmawia, że nie da rady, a zamiast się wziać i powiedzieć „nie, ja to dam radę” $i$ w końcu, $w$ końcu to robie nie, fakt, że może nie ze wszystkim sobie radze, bo..., ale staram sie (RS24k: 161-66)

Pozostający w kraju rodzice skarżą się na przeciążenie obowiązkami domowymi i troskami związanymi z innymi członkami rodziny. Doskwiera im brak obecności partnera w sytuacjach ważnych (pierwsze kroki dziecka) lub trudnych dla rodziny (choroba rodzica) oraz w przypadku kobiet konieczność przejęcia „męskiej roli” w rodzinie. Podkreślane są starania rodziców emigrujących mające na celu „uczestniczenie” w życiu rodziny mimo oddalenia i własne starania, żeby to „uczestnictwo" umożliwić i ułatwić. Dominuje przekonanie o tymczasowości sytuacji, mimo iż sytuacja taka trwa kilka lat.

Podsumowując, emigranci i ich rodziny stykają się z różnymi czynnikami ryzyka zdrowotnego, które w krótszym lub dłuższym okresie moga powodować dolegliwości natury fizycznej lub psychicznej. Respondenci, z którymi przeprowadziłam wywiady, w większości spotkali się z takimi czynnikami ryzyka, jak: praca „3d”, ograniczone relacje społeczne z nie-emigrantami skutkujace trudnościami adaptacyjnymi do nowego otoczenia, niedobory snu, zaburzone relacje w rodzinie, osamotnienie oraz szok kulturowy i marginalizacja społeczna. Zetknięcie się z niektórymi $\mathrm{z}$ wymienionych czynników mogę $\mathrm{w}$ tym miejscu jedynie zasygnalizować. 


\section{Model analizy zdrowia emigrantów. Podsumowanie}

Biorac pod uwage materiał teoretyczny i zgromadzone dane empiryczne, dokonam próby skonstruowania modelu analizy zdrowia emigrantów. W moim przekonaniu badanie to powinno składać się z trzech etapów:

1. Przyjęcie perspektywy mikro-makro - analiza obiektywnych, zewnętrznych uwarunkowań emigracji oraz subiektywnie doświadczanych przez emigrantów stanów związanych z wyjazdem.

2. Badanie za pomoca techniki wywiadu swobodnego czynników ryzyka zdrowotnego - jak często emigranci i ich rodziny się z nimi stykają i czy mogą, mają możliwość, kontrolować ich wpływ. Analiza ta powinna być uzupełniona o zebranie informacji o stanie zdrowia emigrantów, do którego można wykorzystać kwestionariusz ankiety. Badanie to powinno być przeprowadzone w grupie emigrantów i ich rodzin oraz w grupie kontrolnej.

3. Szacowanie wpływu czynników ryzyka zdrowotnego na możliwość wystapienia chorób psychicznych lub somatycznych na podstawie wypowiedzi badanych $\mathrm{z}$ wywiadów swobodnych i informacji zebranych od nich dotyczacych ich stanu zdrowia przed rozpoczęciem emigracji, w trakcie emigracji i po emigracji.

Powyższy model ma charakter roboczy i znajduje się $\mathrm{w}$ procesie tworzenia. Konieczność wypracowania takiego modelu, jak już pisałam na początku artykułu, ma praktyczną doniosłość z uwagi na potrzebe wypracowania dobrze funkcjonujacych polityk migracyjnych w krajach emigracji i w krajach, z których emigranci pochodza. Potrzeba stworzenia omawianego modelu i prowadzenia badań z jego wykorzystaniem ma związek z prawdopodobnie mająca już miejsce większą podatnością emigrantów i ich rodzin na choroby cywilizacyjne, co w dłuższej perspektywie bezpośrednio obciąży systemy zdrowotne i systemy opieki społecznej w tych krajach.

\section{Bibliografia}

Carballo M., Mboup M. (2005), International migration and heatlh, International Centre for Migration and Health, September, [za:] L. Nowakowska (2010), Procesy migracyjne w kontekście zagadnień zdrowia i choroby. Zarys problematyki, [w:] K. Popielski, M. Skrzypek, E. Albińska (red.), Zdrowie i choroba w kontekście psychospołecznym, Wydawnictwo KUL, Lublin.

Davies A. A., Borland R. M., Blake C., West H. E. (2011), The Dynamics of Health and Return Migration, „PLoS Medicine”, vol. 8, s. 1-5. 
Firkowska-Mankiewicz A. (2009), Teorie przyczyn chorób, [w:] A. Ostrowska (red.), Socjologia medycyny. Podejmowane problemy, kategorie analizy, Wydawnictwo IFiS PAN, Warszawa.

Grabowska-Lusińska I., Okólski M. (2009), Emigracja ostatnia?, Wydawnictwo Naukowe Scholar, Warszawa.

Kawczyńska-Butrym Z. (2009), Rodzina - zdrowie - choroba. Kontekst spoteczny i zakres badań empirycznych, [w:] A. Ostrowska (red.), Socjologia medycyny. Podejmowane problemy, kategorie analizy, Wydawnictwo IFiS PAN, Warszawa.

Latoszek M. (1998), Socjologia choroby, zdrowia i medycyny. Zarys problematyki, [w:] Z. Krawczyk, K. Z. Sowa (red.), Socjologia $w$ Polsce, Wydawnictwo WSP, Rzeszów.

Leao T. S., Sundquist J., Johansson S. E., Sundquist K. (2009), The influence of age at migration and length of residence on self-rated health among Swedish immigrants: a cross-sectional study, „Ethnicity \& Health”, vol. 14, s. 93-105.

Markowski K. (2008), Ekonomiczne aspekty migracji, [w:] M. S. Zięba (red.), Migracja wyzwanie XXI wieku, Wydawnictwo KUL, Lublin.

Nettelton S. (2006), The sociology of healh and illness, Polity Press, Oxford.

Niedźwiecki D. (2010), Migracje i tożsamość. Od teorii do analizy przypadku, Nomos, Kraków.

Nowakowska L. (2010), Procesy migracyjne $w$ kontekście zagadnień zdrowia i choroby. Zarys problematyki, [w:] K. Popielski, M. Skrzypek, E. Albińska (red.), Zdrowie $i$ choroba w kontekście psychospołecznym, Wydawnictwo KUL, Lublin.

Piątkowski W. (2002a), Geneza i przedmiot socjologii medycyny, [w:] J. Barański, W. Piątkowski (red.), Zdrowie i choroba. Wybrane problemy socjologii medycyny, Oficyna Wydawnicza ATUT-Wrocławskie Wydawnictwo Oświatowe, Wrocław.

Piątkowski W. (2002b), Zdrowie jako zjawisko spoteczne, [w:] J. Barański, W. Piątkowski (red.), Zdrowie $i$ choroba. Wybrane problemy socjologii medycyny, Oficyna Wydawnicza ATUT-Wrocławskie Wydawnictwo Oświatowe, Wrocław.

Piątkowski W. (2010), Socjologia zdrowia, choroby $i$ medycyny - refleksje na temat przedmiotu badań. Wkład Magdaleny Sokołowskiej, [w:] K. Popielski, M. Skrzypek, E. Albińska (red.), Zdrowie i choroba w kontekście psychospołecznym, Wydawnictwo KUL, Lublin.

Praca Polaków za granica - doświadczenia i plany. Komunikat z badań (2008), CBOS, Warszawa.

Siciński A. (1976), Styl życia - problemy pojęciowe i teoretyczne, [w:] A. Siciński (red.), Styl życia. Koncepcje i propozycje, Wydawnictwo Naukowe PWN, Warszawa.

Skrzypek M., Popielski K., Albińska E. (2010), Zdrowie i choroba jako przedmiot badań interdyscyplinarnych. Wybrane zagadnienia, [w:] K. Popielski, M. Skrzypek, E. Albińska (red.), Zdrowie i choroba w kontekście psychospotecznym, Wydawnictwo KUL, Lublin.

Sokołowska M. (1986), Socjologia medycyny, PZWL, Warszawa.

Synowiec-Piłat M. (2002), Zróżnicowania i nierówności społeczne a zdrowie, [w:] J. Barański, W. Piątkowski (red.), Zdrowie i choroba. Wybrane problemy socjologii medycyny, Oficyna Wydawnicza ATUT-Wrocławskie Wydawnictwo Oświatowe, Wrocław.

Trąbka A. (2009), Wspótczesne polskie migracje z perspektywy transnarodowej, [w:] W. Muszyński, E. Sikora (red.), „Pod wielkim dachem nieba”. Granice, migracje i przestrzeń we wspótczesnym społeczeństwie, Wydawnictwo Adam Marszałek, Torun.

Trzebiatowski J. (2011), Jakość życia w perspektywie nauk społecznych i medycznych systematyzacja ujęć definicyjnych, [w:] „Hygeia Public Health”, no. 46. 
Uramowska-Żyto B. (2009), Socjologiczne koncepcje zdrowia i choroby, [w:] A. Ostrowska (red.), Socjologia medycyny. Podejmowane problemy, kategorie analizy, Wydawnictwo IFiS PAN, Warszawa.

Wasilewski B. W., Kosewski M. (2006), EU-migracje. Następstwa psychologiczne i zdrowotne.

Waszkiewicz L. (2002), Uwarunkowania zdrowia zwiazane ze środowiskiem życia i wykonywana praca, [w:] J. Barański, W. Piątkowski (red.), Zdrowie i choroba. Wybrane problemy socjologii medycyny, Oficyna Wydawnicza ATUT-Wrocławskie Wydawnictwo Oświatowe, Wrocław.

\section{Netografia}

http://mighealth.net/pl/index.php/Konferencja_15_grudnia

http://www.h-ph.pl/pdf/hyg-2011/hyg-2011-1-025.pdf

www.rpo.gov.pl/pliki

\section{Health and sickness factors in the context of work migration A new field of theoretical and practical research in medical sociology}

The article consists of three parts. First part includes analyses concerning problems in medical sociology and applied/used scientific approaches. Second part of the text examines the condition of migrants' health. It has been based on the researches of both Polish and foreign scientists in the field. Third part includes the results of the author's own research and an attempt to review strong and weak sides of both: the study of health risk factors in the context of migration, the analysis of migrants' health condition with the use of qualitative data provided in a free-form interview, as well as, a question of future prospect of creating a model for migrants' health analysis.

Key words: pendulum migration, health, sickness, health risk, life style, the quality of life, health inequality. 